\title{
HEAT-APPLICATOR MACHINE FOR WEED CONTROL
}

\author{
Roger T. Spagnolo ${ }^{*}$, Tiago V. Custódio', César S. de Morais', \\ Ângelo V. dos Reis ${ }^{1}$, Antônio L. T. Machado ${ }^{1}$
}

${ }^{1 *}$ Corresponding author. Universidade Federal de Pelotas (UFPel)/ Pelotas - RS, Brasil.

E-mail: roger.toscan@gmail.com | ORCID ID: http://orcid.org/0000-0002-0287-2561

\section{KEYWORDS}

thermal control, agricultural machinery, organic production.

\begin{abstract}
Pesticide environmental risks and increased weed resistance have encouraged studies for alternatives to herbicides. Among these are weed thermal control methods by controlled heat application machines. Thus, this study aimed to test a prototype of heat-applicator machine as a function of changes in gas pressure, travel speed, and tire traffic effect on plants. Then, three experimental factors were tested: gas pressure $(98,196$, and $245 \mathrm{kPa})$, travel speed $\left(0.56,0.78\right.$, and $\left.1.17 \mathrm{~m} \mathrm{~s}^{-1}\right)$, and tire traffic effect on plants (with and without traffic). The results showed that tire traffic effect on plants and subsequent heat application had no effect on control rate. Weed control rates reached levels considered satisfactory using a heat application speed of $0.56 \mathrm{~m} \mathrm{~s}^{-1}$ associated with gas pressures of 245 or $196 \mathrm{kPa}$, as well as a heat application speed of $0.78 \mathrm{~m} \mathrm{~s}^{-1}$ associated with a gas pressure of $245 \mathrm{kPa}$. A total between 60.9 and $84.9 \mathrm{~kg} \mathrm{ha}^{-1}$ liquefied petroleum gas was required for weed control of around $80 \%$.
\end{abstract}

\section{INTRODUCTION}

Organic food consumption has been attracting more and more people and consequently producers. Family farmers are usually those who produce organic food and weed management is often carried out using manual methods of removal and weeding (Spagnolo et al., 2017).

Thermal weeding is one of the alternatives for weed control in organic and conventional production systems, which do not allow the application of chemicals. According to Datta \& Knezevic (2013), thermal control is an acceptable option for weed management that can be adopted as an alternative to the chemical control, as it eliminates concerns about the direct residual effects on the soil, water, and food quality, reducing the dependence on herbicides, manual weeding, and/or mechanical weeding.

Heat treatment can be a potential alternative tool for weed control in different crops produced organically, such as corn, soybean, and grapevine (Stepanovic et al., 2015; Martelloni et al., 2019). Some crops require more than one heat application for effective control. In this sense, Knezevic et al. (2013) observed that soybean can tolerate a maximum of two heat treatments at the VC and V5 growth stages with no reduction in production.
According to Ulloa et al. (2010), an $80 \%$ weed control is considered an acceptable level for organic agriculture. Several factors influence the design and efficiency of a heat-applicator machine, such as the application speed, gas pressure, and type, height, and angle of burners relative to weeds (Ulloa et al., 2010; Dress \& Balah, 2016). In addition, the species, vegetative stage of weeds, and even the time of day when the intervention is carried out influence the efficiency of the heat treatment application (Ulloa et al., 2012). According to Datta \& Knezevic (2013), the control of grass species can be improved by a second heat application within 7 to 10 days after the first one.

Kang (2001) carried out experiments with a prototype of a heat-applicator machine and found that the higher the application rate of liquefied petroleum gas (LPG), the higher the level of weed control. Mojzis et al. (2015) observed that the lower the heat application speed, the higher the weed control rate. Neilson et al. (2017) developed an implement to carry out soil tillage associating flames and mechanical cultivation, but its drawback is the need to disturb the soil.

Thus, this study aimed to evaluate a prototype of a heat-applicator machine according to the variation of gas pressure, travel speed, and effect of the tire traffic on plants.

\footnotetext{
Area Editor: Murilo Aparecido Voltarelli

Received in: 1-4-2020

Accepted in: 7-6-2020
}

${ }^{1}$ Universidade Federal de Pelotas (UFPel)/ Pelotas - RS, Brasil. 


\section{MATERIAL AND METHODS}

The experiment was conducted in an area belonging to Embrapa Temperate Agriculture at the Cascata Experimental Station, located in Pelotas, RS, Brazil. The approximate geographic location is $31^{\circ} 37^{\prime} \mathrm{S}$ and $52^{\circ} 31^{\prime} \mathrm{W}$, with an altitude of $181 \mathrm{~m}$.

The experimental area of approximately $2500 \mathrm{~m}^{2}$ was prepared (plowed and harrowed) at 20 days before the experiment was set up. The area was divided into four blocks composed of 18 plots. Each block represented one of four replications of the $3 \times 3 \times 2$ factorial, with three experimental factors consisting of gas pressure (98, 196, and $245 \mathrm{kPa})$, travel speed $\left(0.56,0.78\right.$, and $\left.1.17 \mathrm{~m} \mathrm{~s}^{-1}\right)$, and effect of the tire traffic on plants (with and without traffic), thus totaling 72 plots subdivided into four blocks, featuring an experimental design of randomized blocks.

Each plot was $2 \mathrm{~m}$ wide and $15 \mathrm{~m}$ long, with $5 \mathrm{~m}$ before and $5 \mathrm{~m}$ after each plot in the longitudinal direction being used to maneuver and stabilize the travel speed. The data collection was carried out using two strips of $0.4 \times 0.4$ $\mathrm{m}$, one in the trail left by the passage of the rear tire and another in the central part of the tractor track width.

A $4 \times 2$ front-wheel drive (FWD) tractor, with a 42 $\mathrm{kW}$ power was used in the experiment. The prototype of the heat-applicator machine composed of four rows of heat application was coupled to the tractor (Figure 1). The prototype was constructed according to the specifications determined by Spagnolo et al. (2018) and the conceptual project proposed by Spagnolo et al. (2019).

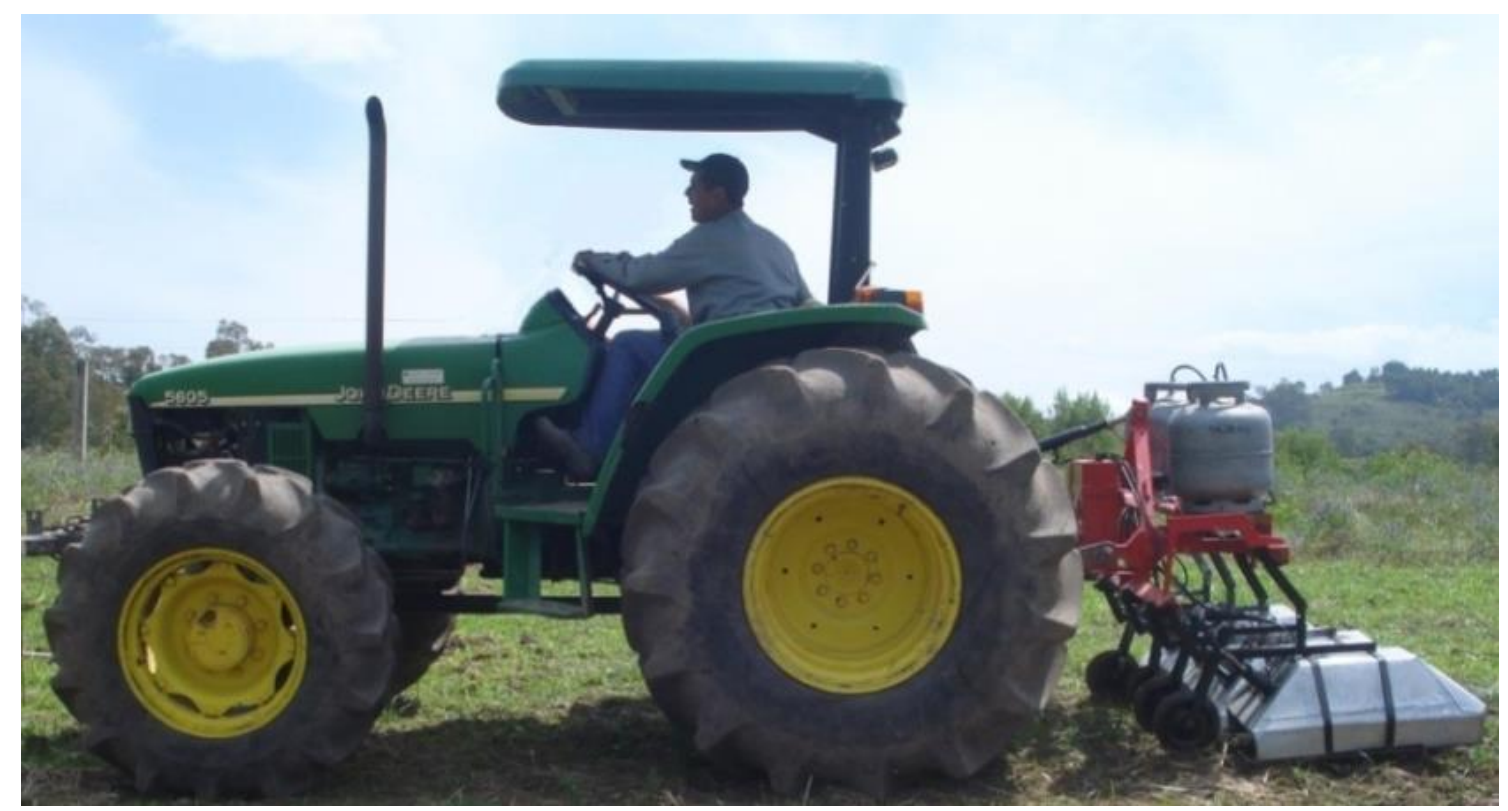

FIGURE 1. Tractor and heat-applicator machine assembly.

Two heat-applicator nozzles were fixed for each row at a $0.3 \mathrm{~m}$ height and $30^{\circ}$ angle relative to the ground in the opposite direction to the machine displacement, which was maintained constant during the tests.

A visual inspection was carried out in each of the 72 plots used in the experiment at the application time to identify the weeds in the area. Several plant species were found, for example, Portulaca oleracea, Amaranthus sp., Ipomoea purpurea (L.), Hydrocotyle bonariensis, Leonurus sibiricus, Vicia sativa, Cynodon dactylon (L.), Sida sp., Euphorbia heterophylla (L.), Raphanus sp., Brachiaria plantaginea, Galinsoga sp., Bidens pilosa (L.), Richardia brasiliensis, Cyperus rotundus (L.), and Alternanthera philoxeroides. According to the $\mathrm{BBCH}$ scale (Hess et al., 1997), the plants were between stages 0 (germination/sprouting) and 3 (elongation of branches or growth of the leaf rosette/development of the main stem).

The experiment was carried out in the afternoon, as recommended by Ulloa et al. (2012), who described that the highest efficiency of the heat-applicator machine is achieved when used during the period of the day when the leaves have less humidity, which occurs at dusk, after a long period of exposure to the sun.

The proportion of desiccated weeds was measured using photographs obtained right after the thermal control (0 DAT) and at 3 and 7 days after the thermal treatment ( 3 and
7 DAT, respectively) for further analysis. The images were generated using a 7.2-megapixel resolution Sony Cyber-shot digital camera, which was connected to a tripod, allowing the generation of images at a 1-m height, constant relative to the plants. The coverage area of these images was defined using a wooden frame with dimensions of $0.4 \times 0.4 \mathrm{~m}$.

The software Spring 5.2, provided by INPE (National Institute for Space Research), was used to analyze these images. The images were cropped aiming at the delimitation of the area under study. The original color images were separated into the channels that compose them. Thus, each original image generated three gray-level images, called red, green, and blue channels.

However, only the red and green channels were used as a function of the spectral behavior of the targets present in the images (green vegetation, dry vegetation, and soil) in the visible portion of the electromagnetic spectrum. Subsequently, an algebraic subtraction operation was performed between the green and red channels, which generated the fourth image (subtracted).

Visual analysis was performed between the original photograph and the subtracted image to define a limit above which the resulting values were representative of green vegetation. The fifth image (sliced) was obtained after defining this limit, which represents the green vegetation, as shown in Figure 2. 


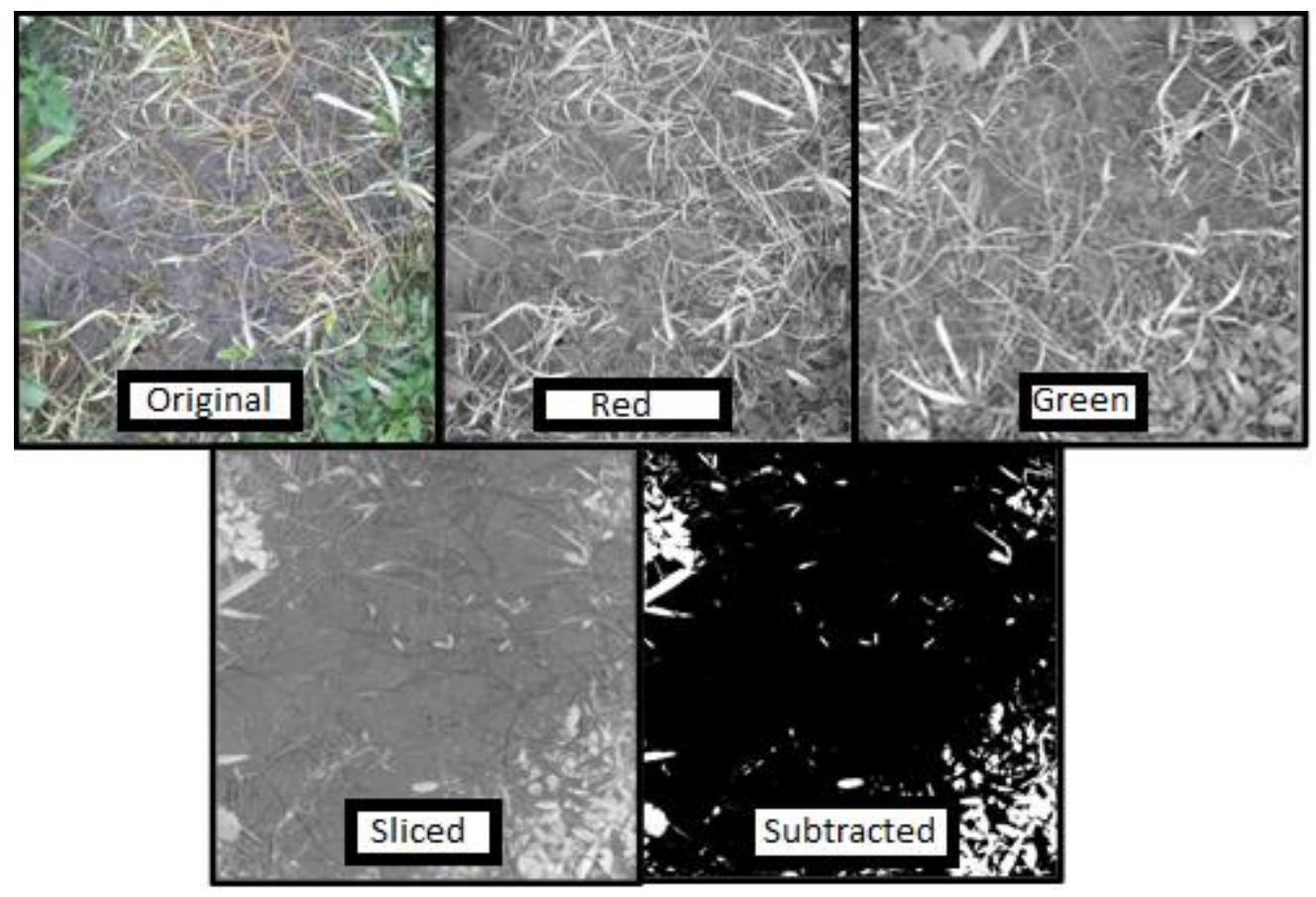

FIGURE 2. Image analysis.

The control rate was determined by comparing the proportion of pixels representative of the green vegetation between the images obtained immediately after the heat treatment application (0 DAT) and those obtained at 3 and 7 days after the treatment ( 3 and 7 DAT, respectively).

Gas consumption for each of the nine combinations between pressure and travel speed was determined in the laboratory. For this, a 10-gram precision scale was used. Consumption was obtained according to the mass consumed for 3 minutes, with the heat-applicator nozzle regulated at the pre-determined pressures.

Gas consumption per hectare was estimated considering an effective working width of $1.8 \mathrm{~m}$, besides the speeds used during the experiment. The unit value of $\mathrm{R} \$$ 80.00 to refill an LPG cylinder with a capacity of $13 \mathrm{~kg}$ was used to determine the cost. The data were analyzed using the statistical program Assistat 7.7 beta.

\section{RESULTS AND DISCUSSION}

The analysis of variance for the variables of speed, pressure, and wheelset at 3 and 7 days after the heat treatment showed no interaction between factors and the variables speed and pressure showed significance at a $5 \%$ level. However, the F-test pointed out no significant difference for the factor wheelset, which proves that plant lodging and subsequent heat application does not imply an increase or decrease in the weed control rate.

Considering the study by Neilson et al. (2017), who used two weed control techniques in a single operation, it was thought in the future to increase mechanisms at the front of the tested prototype to lodge the weeds before heat treatment to provide an increase in their control. However, this hypothesis was discarded with the results of the present experiment.

Table 1 shows that the speed of $1.17 \mathrm{~m} \mathrm{~s}^{-1}$ had no satisfactory results, providing mean values of the plant control rate significantly lower than speeds of 0.56 and 0.78 $\mathrm{m} \mathrm{s}^{-1}$. Therefore, the lower the speed of heat application, the higher the weed control rate. Similar results were found by Mojzis et al. (2015).

TABLE 1. Test of means for weed control considering the factors speed and pressure at 3 and 7 days after the heat treatment (DAT).

\begin{tabular}{lcc}
\hline & & Plant control \\
\hline Speed & $3 \mathrm{DAT}^{*}$ & $7 \mathrm{DAT}^{*}$ \\
\hline $\mathrm{S} 1-0.56 \mathrm{~m} \mathrm{~s}^{-1}$ & $0.61020 \mathrm{a}$ & $0.68693 \mathrm{a}$ \\
$\mathrm{S} 2-0.78 \mathrm{~m} \mathrm{~s}^{-1}$ & $0.56917 \mathrm{a}$ & $0.59616 \mathrm{a}$ \\
$\mathrm{S} 3-1.17 \mathrm{~m} \mathrm{~s}^{-1}$ & $0.36978 \mathrm{~b}$ & $0.35098 \mathrm{~b}$ \\
\hline Pressure & & $0.35653 \mathrm{~b}$ \\
$\mathrm{P} 1-98 \mathrm{kPa}$ & $0.34753 \mathrm{c}$ & $0.58936 \mathrm{a}$ \\
$\mathrm{P} 2-196 \mathrm{kPa}$ & $0.53907 \mathrm{~b}$ & $0.68817 \mathrm{a}$ \\
\hline
\end{tabular}

*Means followed by the same letter in the column do not differ statistically from each other by the Tukey's test at $5 \%$ probability. 
Table 1 also shows that the higher the gas pressure, the higher the weed control rate, corroborating with Ulloa et al. (2010). The LPG consumption can be reduced by reducing the time of plant exposure to the heat applicator nozzles, which is possible with an increase in the operation speed or a decrease in LPG pressure (Ulloa et al., 2010).
Table 2 shows the weed control rate and gas consumption and cost per hectare according to the combination of different levels of speed and pressure used during the experiments. Only two treatments (S2P2 and S3P3) showed a lower control rate at 7 DAT than at 3 DAT, which is due to the regrowth and/or recovery of some plants.

TABLE 2. Weed control rate and gas consumption and cost per hectare.

\begin{tabular}{|c|c|c|c|c|}
\hline \multirow{2}{*}{ Treatment } & \multicolumn{2}{|c|}{ Control rate $(\%)$} & \multirow{2}{*}{ Consumption $\left(\mathrm{kg} \mathrm{ha}^{-1}\right)$} & \multirow{2}{*}{ Cost $\left(\mathrm{R} \$ \mathrm{ha}^{-1}\right)$} \\
\hline & $3 \mathrm{DAT}$ & $7 \mathrm{DAT}$ & & \\
\hline S1P1 & 39 & 42 & 45.19 & 278.09 \\
\hline $\mathrm{S} 1 \mathrm{P} 2$ & 61 & 79 & 70.91 & 436.37 \\
\hline S1P3 & 82 & 86 & 84.88 & 522.34 \\
\hline $\mathrm{S} 2 \mathrm{P} 1$ & 45 & 45 & 32.45 & 199.69 \\
\hline $\mathrm{S} 2 \mathrm{P} 2$ & 62 & 60 & 50.91 & 313.29 \\
\hline $\mathrm{S} 2 \mathrm{P} 3$ & 64 & 74 & 60.94 & 375.02 \\
\hline S3P1 & 20 & 20 & 21.63 & 133.11 \\
\hline $\mathrm{S} 3 \mathrm{P} 2$ & 38 & 38 & 33.94 & 208.86 \\
\hline S3P3 & 52 & 46 & 40.62 & 249.97 \\
\hline
\end{tabular}

Regrowth was monitored and occurred, in general, around the tenth day after the heat treatment, confirming the results found by Kang (2001), Ulloa et al. (2010), and Datta \& Knezevic (2013). Moreover, some plants regrew faster and others more slowly, varying according to the flame intensity generated by the heat-applicator nozzles, allowing inferring that the higher amount of gas, the slower the plant regrowth.

Control is often understood as eradication, which is characterized by high economic and environmental costs, making it unfeasible. According to Lorenzi (2000), weed control reduces infestation but does not necessarily result in its complete elimination.

As shown in Table 2, the use of lower speed $(0.56 \mathrm{~m}$ $\mathrm{s}^{-1}$ ) associated with higher pressure (245 kPa) (S1P3 treatment) resulted in the highest rate of weed control, whether for evaluations performed at 3 DAT, with an $82 \%$ control, or 7 at DAT, with a $86 \%$ control. Although the use of the S1P3 treatment had a good control rate, the LPG consumption was very high $\left(84.9 \mathrm{~kg} \mathrm{ha}^{-1}\right)$, representing a cost of $\mathrm{R} \$ 522.34 \mathrm{ha}^{-1}$ per application, which makes the activity costly compared to pesticide application, but much cheaper when considering the weeding method. Model \& Favreto (2010) reported that the cost for weed control was $\mathrm{R} \$ 2,736.00$ using the weeding method with six interventions, $\mathrm{R} \$ 629.00 \mathrm{ha}^{-1}$ using six glyphosate applications (2.5 $\mathrm{L}$ ai ha $\left.{ }^{-1}\right), \mathrm{R} \$ 468.00 \mathrm{ha}^{-1}$ using five diuron applications (2.4 $\left.\mathrm{L}_{\text {ai ha }}{ }^{-1}\right), \mathrm{R} \$ 621.00 \mathrm{ha}^{-1}$ using three diuron + glyphosate applications $\left(2.4+2.5 \mathrm{~L} \mathrm{ai} \mathrm{ha}^{-1}\right)$, and $\mathrm{R} \$ 653.00$ $\mathrm{ha}^{-1}$ using six atrazine + simazine applications $\left(3.0 \mathrm{~L} \mathrm{ai} \mathrm{ha}^{-1}\right)$.
The results obtained at 7 DAT (Table 2) indicated that the use of the intermediate pressure of $196 \mathrm{kPa}$ associated with the lowest speed of $0.56 \mathrm{~m} \mathrm{~s}^{-1}$ (S1P2 treatment) provided a plant control rate of $79 \%$. Moreover, the control rate reached $74 \%$ for a heat application at the intermediate speed of $0.78 \mathrm{~m} \mathrm{~s}^{-1}$ associated with the highest gas pressure of $245 \mathrm{kPa}$ (S2P3 treatment). Ulloa et al. (2010) defined the $80 \%$ control as a satisfactory level. Therefore, the association of the $\mathrm{S} 2 \mathrm{P} 3$ treatment provided an interesting weed control level $(74 \%)$ and an LPG consumption of $60.9 \mathrm{~kg} \mathrm{ha}^{-1}$, representing a cost of $\mathrm{R} \$$ $375.02 \mathrm{ha}^{-1}$.

According to Mojzis et al. (2015), the heat distribution time is four times longer using a speed of 0.56 $\mathrm{m} \mathrm{s}^{-1}$ than $1.12 \mathrm{~m} \mathrm{~s}^{-1}$. The use of lower speed also leads to a one-third increase in the temperature that reaches weeds. Another factor that could have increased the efficiency of the tested prototype is related to the height and angle of the burners relative to the weeds, which were $0.30 \mathrm{~m}$ and $30^{\circ}$, respectively, in the present experiment. According to Dress $\&$ Balah (2016), a speed of $0.42 \mathrm{~m} \mathrm{~s}^{-1}$, a gas pressure of 196 $\mathrm{kPa}$, a burner height of $0.25 \mathrm{~m}$, and an angle of $45^{\circ}$ provided a $54.6 \%$ efficiency in weed control, reaching $72.0 \%$ with an application height of $0.15 \mathrm{~m}$.

Figures $3 \mathrm{a}$ and $3 \mathrm{~b}$ show that the weed control rate increased proportionally to gas consumption, as observed by Kang (2001), who reported that approximately $40 \mathrm{~kg} \mathrm{ha}^{-1}$ of LPG provides a weed control between 80 and $90 \%$. 


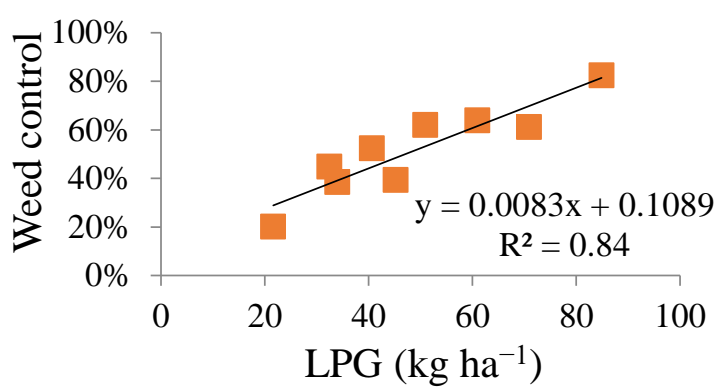

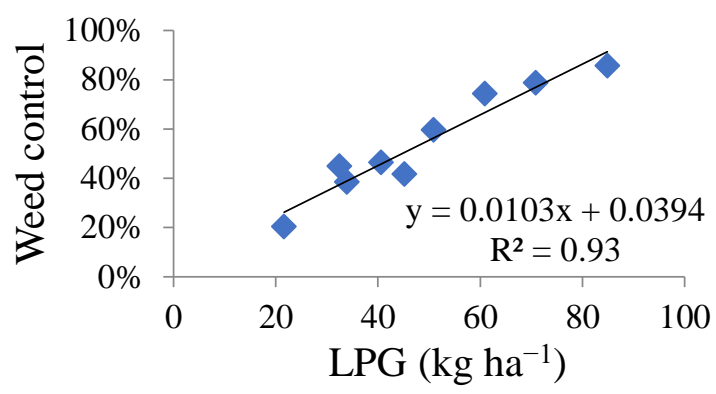

FIGURE 3. Gas consumption and plant control level at 3 (a) and 7 DAT (b).

The equation in Figure $3 \mathrm{~b}$ shows that $77.6 \mathrm{~kg} \mathrm{ha}^{-1}$ of LPG is required to reach an $80 \%$ control. Mojzis (2002) used between 50 and $60 \mathrm{~kg} \mathrm{ha}^{-1}$ of LPG to reach a weed control rate above $80 \%$, while Ulloa et al. (2010) used doses from 40 to $86 \mathrm{~kg} \mathrm{ha}^{-1}$ of LPG to obtain a $90 \%$ weed control.

The LPG doses varied because these authors used the heat treatment technique in different species and stages of plant development, with different water levels in the plants. Moreover, the travel speed of the heat applicator and height and angle of the applicator nozzle are factors that influence the amount of gas consumed in the application and the weed control efficiency (Ulloa et al., 2010; Dress \& Balah, 2016).

According to Spagnolo et al. (2017), organic producers need a device capable of controlling weeds without pesticide application. In addition, most of these farmers, who usually own small farms with a monthly family income of approximately $\mathrm{R} \$ 5,000.00$, use weeding and manual removal as a control technique.

The results of the present study indicate that the prototype used was efficient to control weeds, being able to be improved with a reduction in height and modification in the angle of burners relative to the weeds. The heatapplicator machine is a viable alternative for organic food producers, as it has an estimated production cost lower than R\$ 3,000.00 and does not require removal or weeding techniques, which are arduous and costly control methods.

\section{CONCLUSIONS}

The heat-applicator machine was efficient in controlling weeds, being a viable alternative for family farmers who produce organic food.

The tire traffic on plants and subsequent heat application showed no effect on the weed control rate.

Weed control rates reached levels considered satisfactory using a heat application speed of $0.56 \mathrm{~m} \mathrm{~s}^{-1}$ associated with gas pressures of 245 or $196 \mathrm{kPa}$, as well as a heat application speed of $0.78 \mathrm{~m} \mathrm{~s}^{-1}$ associated with a gas pressure of $245 \mathrm{kPa}$.

A total between 60.9 and $84.9 \mathrm{~kg}$ ha-1 of LPG was required for weed control of around $80 \%$.

\section{REFERENCES}

Datta A, Knezevic SZ (2013) Flaming as an alternative weed control method for conventional and organic agronomic crop production systems: a review. Advances in Agronomy 118:399-428. DOI:

https://doi.org/10.1016/B978-0-12-405942-9.00006-2
Dress A, Balah M (2016) Using flame for weed control in some crops. Journal of Soil Sciences and Agricultural Engineering 7:751-756. DOI: http://dx.doi.org/10.21608/jssae.2016.40368

Hess M, Barralis G, Bleiholder H, Buhr L, Eggers Th, Hack H, Staus R (1997) Use of the extended BBCH scale - general for the descriptions of the growth stages of mono; and dicotyledonous weed species 37:433-441. DOI: https://doi.org/10.1046/j.1365-3180.1997.d01-70.x

Kang WS (2001) Development of a flame weeder. American Society of Agricultural Engineers 44:10651070. DOI: http://dx.doi.org/10.13031/2013.6428.

Knezevic SZ, Stepanovic S, Datta A, Nedeljkovic D, Tursun N (2013) Soybean yield and yield components as influenced by the single and repeated flaming. Crop Protection 50:1-5. DOI:

https://doi.org/10.1016/j.cropro.2013.03.014

Lorenzi H (2000) Manual de identificação e controle de plantas daninhas: plantio direto e convencional. Nova Odessa, Instituto Plantarum, v5, 399p.

Martelloni L, Raffaelli M, Frasconi C, Fontanelli M, Peruzzi A, D'onofrio C (2019) Using flaming as an alternative method to vine suckering. Agronomy 147(9):114. DOI: https://doi.org/10.3390/agronomy 9030147

Model NS, Favreto R (2010) Comparação de custos de tratamentos de controle de plantas daninhas em abacaxizeiro cultivado no Rio Grande do Sul, Brasil. Pesquisa Agropecuária Gaúcha 16:45-50.

Mojzis M (2002) Energetic requirements of flame weed control. Research in Agricultural Engineering 48:94-97.

Mojzis M, Vitázek I, Varga F, Lindák S (2015)

Experimental determination of lethal doses of heat in thermal weed control. Research in Agricultural Engineering 61:9-12. DOI: https://doi.org/10.17221/20/2015-RAE

Neilson B, Bruening C, Stepanovic S, Datta A, Knezevic SZ, Gogos G (2017) Design and field testing of a combined flaming and cultivation implement for effective weed control. Applied Engineering in Agriculture 33:4354. DOI: https://doi.org/10.13031/aea.11719 
Spagnolo RT, Oldoni A, Custódio TV, Machado ALT, Reis AV (2017) Organic production: properties characterization and mechanical situation on weed control. Engenharia na Agricultura 5(6):517-525. DOI: https://doi.org/10.13083/reveng.v25i6.796

Spagnolo RT, Oldoni A, Custódio TV, Reis AV, Machado ALT (2018) Design specifications of a heat applicator weed controller device for family farms. Ciência Rural 48(2):e20170243. DOI: http://dx.doi.org/10.1590/0103$8478 \mathrm{cr} 20170243$

Spagnolo RT, Oldoni A, Custódio TV, Reis AV, Machado ALT (2019) Conceptual design of a thermal weed control machine. Ciência Rural 49(3):e20180673. DOI: http://dx.doi.org/10.1590/0103-8478cr20180673
Stepanovic S, Datta A, Neilson B, Bruening C, Shapiro C, Gogos G, Knezevic SZ (2015) The effectiveness of flame weeding and cultivation on weed control, yield and yield components of organic soybean as influenced by manure application. Renewable Agriculture and Food Systems 31(4):288-299. DOI: $10.1017 / S 1742170515000216$

Ulloa SM, Datta A, Knezevic SZ (2010) Tolerance of selected weed species to broadcast flaming at different growth stages. Crop Protection 29:1381-1388. DOI: https://doi.org/10.1016/j.cropro.2010.07.017

Ulloa SM, Datta A, Bruening C, Gogos G, Arkebauer T, Knezevic SZ (2012) Weed control and crop tolerance to propane flaming as influenced by time of day. Crop Protection 31:1-7. DOI:

https://doi.org/10.1016/j.cropro.2011.09.005 